\title{
The Three-Year Experience with the Community Reinvestment Act
}

\author{
NORMAN N. BOWSHER
}

REDIT is a scarce commodity. As lenders allocate available funds on the basis of at variety of considerations, inching price (interest rates), ability to repay, maturity of the loan and costs of servicing, it is generilly diffeult for an outside observer to detemine why one loan application is refused while an apparently similar one is accepted.

During the 1970 s, banks and thrift institutions were charged witl "redlining" in allocating credit. Many charged that lenders, in essence, drew a line (presumably red) around certain areas on a map and deliberately reduced the supply of mortgage and other credit to residents of those areas. Redlining was credited with both unfarty discriminating among those seeking credit and hastening the economic decline of the affected areas. Lenders, theoretically, did this bectuse they were shortsighted, bigoted or insensitive to the needs of these individuals and communities. ${ }^{1}$

In response to such charges, Congress passed the Community Reinvestment Act (CRA), effective November 6,1978 , to encourage financial institutions to meet the credit needs of their local communities. This article discusses redlining and examines the CRA experience during the three years of its existence. Since a study by the Council of State Plaming Agencies has recommended enactment of

"Take the Woney and Run! Redining in Brooklyn (New York Public Interest Gromp, Inc, 1976), pp. 13-16; and Redlined: A National Surcey by National Peoples Acfion of Mortogtge Lendins Policies in the United States, October 1976 (U.S. Senate Hearings, November 23, 1976, pp, 154-87). a law similar to the CRA, but amed at increasing credit to small businesses in the bank's community, this is an appropriate time to review the CRA experience. $^{2}$

\section{Mon Nan}

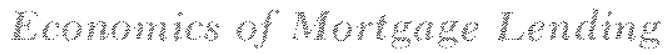

The purchase of a home is typically the largest financial outlay that an individual makes in his lifetime, usually amounting to two or more years of a buyer's income. Home purchasers generally rely on substantial credit to facilitate their purchases since they do not have sufficient savings readily available to buy the home outright.

By mid-1981 total mortgage debt in the country amounted to $\$ 1.5$ trillion, more than 50 percent greater than the total federal debt. This mortgage credit was granted by a vast number of diverse lenders. Savings and loan associations held 34 percent of the debt, commercial banks had 18 percent, life insurance companies carried 9 percent, and federal and related agencies held 8 percent. The remaining 31 percent of the mortgage debt was distributed anong mutual savings binks, mortgage pools or trusts, relatives and other individuals,

"Beth K. Vogt, "Small Busness Lom Act Unged," American Banker, December 24, 1981 . 
mortgage companies, state and local credit agencies, credit unions and pension funds.

Because of the unique features of each property, the limited knowledge about borrowers outside the community, and legal restrictions on some lenders, most mortgage loans are granted by lenders located in the area of the property to be financed. Nevertheless, there is, in essence, a national mortgage market, and terms on mortgages vary only slightly between regions.

The broader market reflects the fact that some lenders, such as insurance companies, in searching for the most profitable opportunities, lend in various sections of the country. Also, mortgage bankers frequently resell mortgages to institutions situated in other parts of the country to enable them to make additional loans locally. FHA insurance and the secondary markets further improve the acceptance of mortgages outside the local community. In addition, savings tend to flow from areas of relatively low interest rates to areas of relatively higher interest rates. As a result, there is, in reality, a national mortgage makket, bringing competition for mortgages into virtually every locality.

Since lenders are in business to maximize their wealth, it is natural for them to seek the most profitable loans available. It is rational, therefore, in determining whether to grant a loan, for lenders to consider such economic factors as the present and future value of the collaterat, the income, wealth and other measures of the creditworthiness of the borrower, and the probable collection costs, in addition to the interest rate charged. On the other hand, it is inational for lenders to refuse to lend for reasons unrelated to the likely proftability of the loan.

\section{Wheoreticul Obiections to the

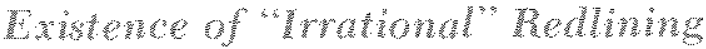

To forego profitable opportunities by discriminating against potential borrowers on the basis of non-economic criteria is generally considered irrational behavior on the part of lenders. Imposing less favorable terms in one area than another, or refusing to lend altogethen, when not justified by differences in risk or cost, is inconsistent with the self interest of lenders or borrowers. If private lenders are profit maximizers, non-profitable redlining would be of limited duration. ${ }^{3}$ Althongh some lenders, at times,

\footnotetext{
BSee Jack M. Guttentag and Susan M. Wachter, Redlining and Pablic Policy, Monograph Series In Finance and Economics, Monograph 1980-1 (New York University), p. 5 .
}

may derive satisfaction from denying certain loans for non-economic reasons, competition from other lenders who seek such profitable loans assures that such actions are neither common nor widespread.

Despite its practical drawbacks, many believe that such redlining is common and that laws are needed to correct this abuse. ${ }^{4}$ These observers believe that many financial institutions exercise local monopoly power; thus the potential competition to reduce unprofitable redlining is severely limited. Hence, lenders allegedly have sufficient market power to indulge their lending prejudices for a considerable time. Although a lender with sufficient monopoly power can become lax or biased if he chooses, however, most monopolist lenders have pecuniary incentives to make the most profitable loans, incentives that are reinforced when management is accountable to stockholders. An exception, where prejudicial discrimination may be practiced without pecuniary cost, is a monopoly lender already so profitable that it fears public policy actions may be forthcoming if it becomes even more profitable. ${ }^{5}$ This does not appear to be a problem for mortgage lenders.

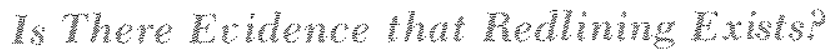

The principal method of demonstrating the existence of redlining is to count mortgages made by certain lenders in an inner-city, low-income area and in a sububan, high-income area for about a year and compare the two figures. ${ }^{6}$ Such arguments were supported by data supplied by financial institutions under the Home Mortgage Disclosure Act. These data, combined with census infomation on housing, income and population, indicate that low-income areas receive proportionately less credit than other neighborhoods.

However, these studies have serious shortcomings. Most careful analyses have generally been consistent with the implications cited above for

\footnotetext{
"George I. Benston, "The Persistent Myth of Redlining," Fortune (March 1:3, 1978), pip. 66-69.

SSee Armen A. Alchiar and Reuben A. Kessel, "Competition, Monofoly, and the Pursut of Money," Aspects of Labor Ecar nomics (National Bureau of Economic Pesearch, 1962), pp. 157. 83. Also, Alfred Nicols, "Stock Versus Mutual Savings and Loan Associations: Some Evidence of Differences in Behavior," Anericon Economie Reciew (May 1967), pp. 337-46.

"See Michzel Agelizto II and David Listokin, "Redlining in Perspective: An Fvaluation of Appronches to the Urban Mortgatge Dilenma," in Donald Phares, ed., A Decent Home and Enciroment: Hotsing Orban America Ballinger Publishing Company, 197i
} 
profit-maximizing lenders. Two studies - for Sacramento, Califomia and Lousville, Kentucky demonstrated that arguments advanced to show redlining omitted many important sources of credit such as mortgage bankers and private funds. ${ }^{7}$ In an analysis of datit provided by Toledo, Ohio, savings and loan associations, the demand for mortgages was also found to be an important onitted factor. ${ }^{8} \mathrm{~A}$ study of FluA insured mortgage foreclosures in six major cities which focused on the risks (costs) of lending on properties in alleged redlining areas found that differences in loan tems were based on economic rather than prejudicial factors. ${ }^{9}$ Allegations by community groups that properties in low-income areas were systematically underapraised were not supported in a study of savings and loan data for Miami, San Antonio and Toledo. ${ }^{10}$ On the other hand an examination of denials of mortgage applications based on a survey of 176 banks by the Comptroller and the Federal Deposit Insurance Corporation (FDIC) found slight evidence of non-economie discrimination. ${ }^{11}$

An indepth study of the Rochester, New York, metropolitan area found insufficient evidence to conchude that redlining was a serious problem. ${ }^{12}$ Its authors noted that previous inquiries claiming to find significant amounts of redlining made incomplete surveys of lenders (particularly mortgage bankers), ignored the effect of rent controls, used time periods too short for meaningful generalizations, ignored the collateral offered and the creditworthiness of borrowers, or did not compare demands for credit by areas.

\footnotetext{
7 Demnis Dingemans, "Redlining and Mortgage Lending in Sitcramento," Anmals of the Association of American Geographers (Tune 1979), pp, 225-39; and Theodore Koebel, Housing in Loulswille: The Problems of Disinestment (Urban Studies Center, Univessity of Louisville, 1978).

"James R. Ostas, J. David Reed, and Peter M. Huthhiosol: "An Intertemponal Comparison of Urban Mortgage Lending Patterns in the Toledo, Ohio SMSA: 1977 vs. 1975," Unpublished paper (Bowling Green State University, 1979).

9Richard G. Marcis and Everson W. Hull "Analysis of the SocioEconomic Deteminants of Foreclosures on $2219(d)(2)$ and 235 Mortgages," Fedexal National Association Meeting, 1975.

${ }^{10}$ A. Thomals King, ${ }^{\text {An }}$ An Analysis of Mortgage Lending in Thee SMSA's," Office of Exonomic Resench, Federal Home Lam Banch Board (preliminary report; 1979 ).

"1 Harold Black, Rober L. Schwejtzer and Lewis Mandell, "Discrimination in Mortgage Lending:" Americun Economic: Reviet (May 1978), pp. 186-91.

${ }^{12}$ George J. Benston, Dan Horsky, and H. Martio Weingatner, An Empirical Studl of Mortgage Redlining, Monograph Series In Finance and Economics, Monograph 1978-5 (New York OTiversity).
}

Another extensive empirical analysis was made of virtually all home mortgage and home improvement loans granted in Cuyahoga County, the central county of the Cleveland area, from 1977 through 1979. ${ }^{13}$ After controlling for income and other demographic variables, the study concluded that neighborhood racial composition had little impact on either the total number of deed transfers financed by mortgage loans or total housing-related financing. However, it also appeared that the portion of conventional mortgage financing provided by banks and savings and loans was significantly lower in integrated and all-black neighborhoods than in allwwhite neighborhoods. On the other hand, black and racially mixed areas were significantly more likely to be served by mortgage bankers offering $\mathrm{FHA}$ and VA financing. Also, banks and savings and loans were much more likely to make home improvement loans in these areas.

One can obtain additional evidence that irrational redlining does not exist by looking at the operating history of new banks established primarily to lend in low-income areas. Twenty-six black-owned banks, for example, were established to serve this demand in low-income areas in the last 10 years. Of these new banks, five have failed, and at least a dozen others were near collapse before other organizations bailed them out. ${ }^{14}$ Although minority banks came into existence to deal with specific minority credit problems, their lack of success suggests that most creditworthy demands were already being accommodated, although other factors such as management and capitalization may also have played a role.

Further tests of banks' lending behavior support the profitmaximization model. One recent study, using dati on 30,000 commercial bank consumer loans, tested whether sex discrimination existed in credit allocation by banks. ${ }^{15}$ The study found no systematic pattern of sex discrimination - even before the Equal Credit Opportunity Act was passed. Instead, banks typically behaved as profit maximizers, making loans on equivalent terms to equally risky customers, regardless of their sex.

\footnotetext{
${ }^{13 R o b e r t ~ B . ~ A v e r y ~ a n d ~ T h o m a s ~ M . ~ B u y n a k, ~ " M o r t g a g e ~ R e d i n i n g ~}$ Some New Evidence," Econonic Reciew, Federal Reserve Bank of Cleveland (Summer 1981), pp. 18-32.

1" Michael L. King, "Black-Owned Banks Facing Doubts About Their Continued Usefuness," The Wall Street Joumal, August 10,1951 .

${ }^{25}$ Richard I. Peterson, "An Irvestigation of Sex Discrimination in Commercial Bank Direct Consumer Lending," The Bell Jommal of Economics (Autumn 1981), pp. 547-61.
} 


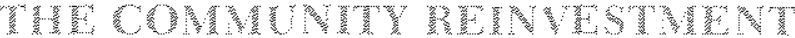

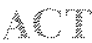

Despite theoretical objections and the lack of evidence that such redlining actually existed, Congress passed the CRA. The congressional action generally reflected the public's sympathy with the anecdotal arguments of those living in blighted areas. The success of community groups in convincing the press and public that lenders were not serving older urban areas was primarily the result of skillful publicity rather than substantial confirming evidence. ${ }^{16}$ The act was intended to elminate irrational redlining in detemining whether a loan application is accepted; lenders were still permitted to evaluate applications on rational economic grounds.

The act specifically requires financial institutions to ". . demonstrate that their deposit facilities serve the convenience and needs of the communities in which they are chartered to do business." It directs four regulatory agencies - the Board of Govemors of the Federal Reserve System, the Comptroller of the Currency, the Federal Home Loan Bank Board (FHLBB), and the FDIC - to encourage each institution under theirjurisdiction to help meet the credit needs of its entire local community.

Under the act, a financial institution is required to adopt a CRA statement, maintain public CRA files and display a CRA notice, which includes information on the avalability of the institution's CRA statement. The CRA statement must include a delineation of the area that comprises the institution's community and a list of principal types of credit that the institution is prepared to extend. The public files must contain any signed comments received from the public about the institution's record of serving the credit needs of its community.

In addition, the CRA requires the regulatory agencies to assess regularly each institution's record of meeting the credit needs of its community, including low-to-moderate income neighborhoods, consistent with the safe and sound operation of the institution. These assessments are taken into acm count in rulings on merger, holding compary and other applications by the institution. Also, the CRA offers anyone the opportunity to challenge any merger, holding company or branching expansion

\footnotetext{
taSee George J. Benston, "Mortgage Redining Research: A Review and Critical Analysis Discussion," The Regrlation of Finnoinal Institutions, Conference Series No. 21 (Federal Reserve Bank of Boston and the National Science Foundation, 1979 , pp. $114-95$
}

plans of financial institutions that are considered umesponsive to the credit demands of their community.

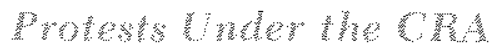

To date, about 100 protests in opposition to the applications of banks and savings and loans on CRA grounds have been filed with the regulatory agencies. Most have been lodged by community orgatnizations, a few have come from the press or individuals, and approximately one-third have been lodged by competitors. Most protests have been against institutions located in or near low-income areas of major cities.

At first, community groups were hesitant about using the CRA to challenge applications, perhaps because of their unfamilarity with the operations of financial institutions and regulatory agencies and becanse most creditworthy demands were being accommodated. Over time, these organizations have gained experience and become more active. A number of protests have been supported by considerable information; these have frequently been instrumental in gaining concessions from financial institutions. ${ }^{17}$

Although there are several technical requirements in the CRA, sucl as displaying a CRA notice in the lobby, protesters have had little complaint conceming them. The chief issue raised in most protests is the failure of the financial institution to serve adequately the housing-related credit requirements of low-income neighborhoods, especially those composed of minorities or those with a shifting racial balance. These complaints typically contend that the lending institution systematically refuses or severely limits credit to certain neighborhoods because of location, age of property or general conditions in the area, with little regard to the creditworthiness of the applicant.

Protests also have been registered on other grounds. These include: the institutions' failure to advertise the avalability of credit in the lower income nelghborhoods; it low level of involvement with government programs, particularly the Small Business Administration and the student loan programs; excessively restrictive mortgage loan policies, such as larger down payments than other

\footnotetext{
7'See Thomas M. Buynak, "The Community Reinvestment Act: Eialy Expentence and Problems," Economic Commentary, Federal Reseve Bank of Cleveland, April 20,1981
} 
lenders in the community require; pre-screening of potential loan applicants; and inadequate efforts to ascertain "community credit needs."

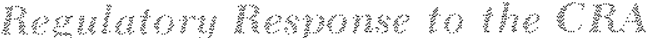

Congress provided little specific guidance in the act as to what is satisfactory or unsatisfactory performance in regard to community reinvestment. The act does not explain how a financial institution's community should be selected, how credit needs atre to be determined, what constitutes low- and moderate-income neighborhoods, or to what extent the act was to be interpreted by considering the costs, liquidity, safety and profitability of the lender. Since the provisions of the act are vague, regulatory agencies have had to both enforce the act and interpret it as well.

The regulatory agencies invited the public to suggest how to interpret and implement the act in a series of hearings held in cities across the nation. 18 To provide a focus for the hearings, a number of questions that the statute raised were included with the public notice of the hearings. ${ }^{9}$ Consequently, the implementation of the act began modestly and cautiously and has been gradually formulated over time. The agencies, evolving their own standards on a case-by-case basis, have examined a variety of evidence in evaluating a lender's CRA performance. ${ }^{20}$

Under the CRA, regulatory agencies have a number of responsibilities. They must regularly assess each lending institution's record of performance in helping to meet its community credit needs. This assessment or inspection covers both the technical compliance with regulations and a qualitative evalvation of the institution's overall performance in serving the credit requirements of its community. The regulatory agencies have agreed on a uniform rating system to provide a consistent application of the act. However, they assigned no explicit weights

\footnotetext{
185ee statement by Philip C. Jackson Jr, Federal Reserte Bullefin (Angust 1978), pp. 631-33.

isee "Community Reinvestment Act of 1977 to Be Implemented," Federat Reserve Bank of Dallas Voice (March 1978), B. 12, for questions posed. Also, see "Community Reinvestment Act Hearing Held at Fed," Federal Reserve Bank of Dillas, Woice (May 1978), pp. 22-24, for a sampling of the mixed comments recelved at the public hearings.

${ }^{20}$ Glenn Canner and Joe M. Cleaver, "The Community Reinvestment Act: A Progress Report," Federal Reserte Bulletin (Februaty 1980), pp. 87-96.
}

Table 1

\section{CRA Examination Ratings of Member}

\section{Banks During 1980}

\begin{tabular}{|c|c|c|}
\hline Rating & Number of & $\begin{array}{l}\text { Percentage } \\
\text { of banks }\end{array}$ \\
\hline 1 outstanding & 31 & $35 \%$ \\
\hline $2 \mathrm{Godd}$ & 328 & 367 \\
\hline 3 Satisfactory & 507 & 567 \\
\hline 4 Needs mprovement & 26 & 29 \\
\hline $5-$ Unsatisfactory & 2 & 02 \\
\hline TOTAL & 894 & 1000 \\
\hline
\end{tabular}

to the assessment factors, since they believed that any such weighting would constrain an institution's responses to local credit demands.

A significant aspect of the CRA inspection is an overall judgmental evaluation of a lender's performance in meeting the credit demands of its community. CRA inspections of a given bank occur roughly every 12 to 18 months and, by and large, have revealed that the banks served the credit needs of their communities (table 1).21 Even in cases of unsatisfactory performance, most potential borrowers were protected by other competitive institutions in the area.

Regulatory agencies take into account both the CRA assessments and actions taken by the lender to bring about future improvement when they evaluate an institution's application for a charter, branch, office relocation, deposit insurance, merger or acquisition. The agencies will deny any application if they judge that the bank or savings and loan has not comm plied with the substantive provisions of the CRA.

Also, since the public may challenge a financial institution's application on CRA grounds, the agen* cies must evaluate the merits of CRA protests and objections when considering an institution's application. To aid protestors, the Federal Reserve System issued Regulation BB, which lists the criteria the Board of Govemors considers in evaluating the CRA record of a bank (see insert). In addition, each Reserve Bank has appointed a Community Affairs Officer whose responsibilities include advising

\footnotetext{
${ }^{21}$ Glenn Canner, "The Community Remvestment Act: A Second Progress Report," Federal Rewerce Bulletin (November 1981), pp. $813-18$.
} 
community gromps and banks on procedures to follow in CRA disputes.

To date, only four applications have been denied on CRA grounds. Three rejections were by the FDIC, two involving branch applications and one a merger. The fouth denial was by the Comptroller of the Currency. The three FDIC cases tollowed protests by community groups; in the other cases, there was no protest. Three of these cases were subsequently approved after specific actions by the institutions - such as hining a full-time community relations officer, improving its marketing programs and committing specific amounts of funds for mortgage and home improvement loans in low-to-moderate income neighborhoods - improved their CRA performance.

The relatively few denials under the CRA, however, is not at reliable measure of the effect of the act on bank lending practices. Because of the act, a number of institutions have changed certain lending practices, and many approvals of applications have been based on commitments to improve CRA performance. Of the 19 protested cases approved by the

\section{Assessing the Record of Performance Regulation BB, Section 228.7}

In comection with its exammation of a State member batik, the Board shall assess the reeord of performanes of the bark in helping to neet the credit needs of it entire community, including low and noderdte- incone neighborloods, eonsistent with safe and sound operation of the bank The Board will ievien the bank , CRA Statement(s) and an signed, witten comments retained by the State menber bank or the Federal Reserve Bank. In addition, the Board will con stder the following factors in assessing a bathks record of performance:

(6) Activities conducted by the State nember bank to ascentain the eredit needs of its eommunity, including the extent of the banks eflorts to communicate witl nenbers of its community regarding the eredit services being provided by tho bank:

(b) The extent of the State menber bank's narketing and special credit-related programs to make nembers of the community aware of the credit senvices offered by the bank.

(c) The extent of participation by the State nember banks board of directors in formulating the bank's policles and retiewing its performance with respect to the purposes of the Community Reinvestment Act.

(d) Any practices intended to disconrage applications for types of credit set forth in the State nember banks CRA Statement(s) (e) The geographic alstribution of the State nenber bank's credit extensions, credit applica tons, and credil denills:

(1) Evillence of prohibited discrininatory or other ille al credit practices.

(g) The State nember bank's record of opening and elosing offices and providing services at offees;

(1) The State nember banks partictpition in diuding meestment, in local community development and redevelopment projects or programs.

(1) The State nember bank's ongination of residential mortgage loans, lousing rehabilitation loans, lome improvement loans, and sinall business or snall farm lowns withn its community, or the purchase of such loans originated in its comnunity,

6) The State nember bank's participation in governmentally-tusured, guaranteed or subst dized loan programs for housing, small businesses, or small fams;

(a) The State nember bank's ability to neet Garious conmunity credit needs based on its francial condition and size, and legal impedi nients, local economic conditions, and other tac tors: and

(1) Other factors hat, in the Board's gudgnent reasonably bear upon the estent to which a State menber bank is helping to neet the credit needs of its entire community. 
Board of Governors, commitments have played a role in seven. ${ }^{22}$

It is the explicit policy of the regulatory agencies to encourage discussion between applicants and protestants to help resolve or narrow their differences. A number of such discussions have been held, and, in six protested cases decided by the Board of Govemors, a privately negotiated agreement between the parties was a factor in resolving the problem. These discussions resulted in commitments by financial institutions to change lending practices and other policies. At times, in private agreements between the parties, lenders have gone much further than the act requires, for example, by allocating specific amounts of mortgage credit in certain depressed areas at interest rates of $1 / 2$ percentage point below the prevailing market rate. ${ }^{23}$

\section{G}

The CRA has been controversial from its inception. Prior to its passage, community groups claimed that irrational redlining was common, while financlal institutions asserted that they were meeting neighborhood credit demands consistent with prudent lending practices. There is little agreement, however, on the extent of the problem, though most careful studies have found little discrimination in lending. Consequently, the desirability of the act and the role, if any, that it should play in credit markets is still in doubt after thee years. The American Bankers Association has requested Congress to repeal the CRA. ${ }^{24}$

Even if some managers of financial intermediaries were willing to lorego profits to satisfy their prejudices, the sizable numbers of lenders operating in most local markets, especially in the major cities where redlining is alleged to be greatest, makes it unlikely that many actual cases of credit unavailability on competitive terms would be observed. The experience of the last three years has been consistent with many economists' views that the lack of credit availability to borrowers catised by irrational redlining is uncommon. Yet, also as expected, the act has placed a burden on lenders, which has caused

\footnotetext{
22lidid.

23ee the orden in the Landmark case, News Pelease, Fedent Reserve Bank of St Lomis. November 30,1979

24 "ABA Calls For Reveal of CRA, Hagh Costs are Cited" Amertcan Banker, December 11, 1981. The ABA contends that costs fir exced the benefits ofCRA and the act merely recuires what good sense dictates anyway - serving the communities.
}

some reallocation of credit and increased the costs of financial intermediation.

The philosophy incorporated in the CRA of requining each financtal institution to give preference in its lending to those in their local community can be questioned. Financial institutions, their stockholders and their depositors are clearly better off if funds are loaned where the interest rates are higher, regardless of location. Similarly, the prospects for increased investment and production are enhanced when credit is allocated efficiently. Competition among lenders, the borrowers best protection against prejudiced lenders, is strengthened when financial institutions seek to make the best loans possible.

Some analysts regarded the passage of the act as a major step toward govemmental allocation of credit. Such concern still exists, even though the regulatory agencies deny that the act and its enforcement allocates credit. ${ }^{25}$ In fact, the Federal Reserve has stated that it will not endorse any agreements to allocate credit. ${ }^{26}$ Yet, when financial institutions desire favorable rulings on applications, and, as part of this process, must demonstrate that the credit needs of low-to-moderate income areas are being adequately served, credit will be allocated differently, if for no other reason than to increase the probability of a favorable ruling. Thus, some financial institutions have atdusted their lending policies to grant more credit in low-to-moderate income areas in their communities.

Another result of the act is that financial institutions have undertaken large projects in which financial risks can be shared. One example of such efforts was in Springfield, Massachusetts, where 11 local commercial and savings banks and two insurance companies combined development efforts to revi-

\footnotetext{
25The Federal Reserve has stated, "Althongh CRA is directed at the problem of meeting sound communty credt needs, it was not intended to establish in regulatory influence on the allowition of credits. In implenenting the Act, the Board has acted on the belief that hanks are in the best position to assess the credit needs of their own local communties..." Federal Reserve System, Community Reinvestment Act, Intomation Statement, January 3, 1980, p. 1 .

${ }^{26}$ (The Board) ". . is aware that many banks have on the ir ow initiative adopted special purpose credit programs, or pilot programs to test new credit oflerings. The Board does not wish to discourage these efforts. However, the Board will closely scrutinize any a areements to ascertain that they are not inconsistent with the safety and soundness of the bank involved, and do not establish a preference for credit extensions inconststent with evenhanded treatment of borrowers..."Federal Reserve Systen, Commmity Reinvestment Act, In fomation Statement, Jimuary 3,1980, p. 3.
} 
talize the downtown area. ${ }^{27}$ The longermin anti competitive implications of creating what are essentially lending catels, however, may be unfavor able for bonowers.

An evaluation of the net impact on the community of CRA-type agreements and commitments by financial institutions to community gtoups is difficult. Perhaps bonowers in low-to-moderate income areas have received somewhat more credit than they would have otherwise received. The costs to depositors, stockholders and other potential borrowers, however, are largely hidden. To the extent that contacts with community groups improve the bunker's knowledge of loan opportunities and risks, and generates new sources of sound loans at current market rates, such activities improve the financial system while removing some inequities. To the extent that bankers engage in these activities merely to create hamonious public relations, they merely increase the costs of financial internediation.

The costs imposed by the CRA on financial intermediation have run into many millions of dollars. The expense of adopting formal policy statements,

${ }^{27}$ See "Investing in the Future of America's Cities: The Banker's Role," Six Catse Studies, prepared by the National Council on Urban Economic Development for the Offee of the Comptrolle: of the Curmency, Conmunity Development Division. appointing community relations officess, familiarizing employees with the legal requirements, holding meetings with community groups, record keeping and reporting must be financed by each lending institution. The administrative costs of the regulatory agencies in periodically assessing each financial institution's CRA performance and in applying CRA standards in the review of each application is a burden on taxpayers. A protested CRA application generates the additional costs of preparing a defense and often delays for six months or more the outcome of the application.

Some have expressed concern that the CRA eventually will reduce the supply of credit in lowincome neighborhoods. A study prepared for the FHLBB found that the act shifted housing-related credit into certan central-city areas, but only in the short run, 28 The regulations also raise costs more shanply for lenders serving these localities, which could eventually result in a reduction in the supply of such credit. With less credit avalable, it becomes more expensive, adversely affecting the low-income areas. Also, when allegation of CRA violations come from competitive institutions seeking to prevent or delay a market entrant, the flow of credit to the local area is impeded, an outcome presumaly ypposite to the act's intent.

${ }^{28}$ Guttentag and Wachter, "Redining and Public Policy." 